\title{
ANALYSIS OF TRENDS FOR DEVELOPMENT OF DISTANTLY EMPLOYMENT IN UKRAINE
}

\section{АНАЛІЗ ТЕНДЕНЦІЙ РОЗВИТКУ ВІДДАЛЕНОЇ ЗАЙНЯТОСТІ В УКРАЇНІ}

\section{Hnidenko Viktoriia ${ }^{1}$ \\ Kaplina Halyna ${ }^{2}$ \\ DOI: http://dx.doi.org/10.30525/978-9934-571-29-9_2}

Abstract. The essence of globalization in the field of labor relations is explored. The mechanism of influence of the global informational environment on the national labor market is described. The subject of this study is labor lawsuits, which arise from the subjects of labor law in the exercise of their right to work through forms of remote employment and with the growth of the Internet. The purpose of the research aimed at analyzing existing and developing new labor-law approaches to the regulation of non-traditional, modern forms of employment and ways to realize the right to work in modern society is formulated. In accordance with the stated goal, the task of determining the factors influencing the development of the typology of non-standard employment, clarification of the concept of "digitalization" and analysis of the provisions of the Concept of the development of the digital economy of Ukraine will be addressed. It is indicated that an important direction of the research is also the justification for the need for a meaningful revision of the concepts of labor law, such as the workplace of an employee, labor function, work mode, work schedule, etc. Today the state lacks a perspective vision of the future employment model of the population, oriented not only to increase the quantitative indicators and to shun labor relations, but above all to ensure qualitative changes in the workplace. It has been discovered that far more people prefer remote independent work to order, taking into account a number of criteria: dis-

\footnotetext{
${ }^{1}$ Postgraduate Student of the Faculty of Law,

Volodymyr Dahl East Ukrainian National University, Ukraine

${ }^{2}$ Ph.D. in Law,

Associate Professor at Department of Law,

Volodymyr Dahl East Ukrainian National University, Ukraine
} 
placement in the demographics of the labor force, the formation of a new type of employee, the development of mobile technologies, a wide network of social connections, innovative education and family status ( worker with family responsibilities). It is proved that the process of digitalization entails modernization of the workplace, the basic principles of which should be: providing employees with mobile communication, using mobile business applications, participating in videoconferences, proper infrastructure and safe digital space. Describes the digital labor market, serving as a new segment in the existing market, whose share and weight is constantly growing. Unfortunately, however, it has to be noted that, despite the large number of people engaged in the digital labor market, in the current labor legislation there is no legal regulation of this form of employment as a distant work, which does not allow freelance persons to be fully to realize the right to work guaranteed by the Constitution of Ukraine.

\section{1. Вступ}

Новизна теми та актуальність наукових рішень. Безперечним є факт, що у сучасних умовах відбувається формування глобального інформаційного середовища. Це є динамічним та об'єктивним процесом, пов'язаним з розвитком інформаційно-комп'ютерних технологій та розповсюдженням їх у всіх напрямах суспільного життя. Наразі констатуємо перехід від індустріальної до інформаційної економіки, що обумовлює процеси трансформації правового регулювання трудового права, зміну змісту трудових правовідносин, характеру та форм зайнятості.

На жаль, сьогодні державі не вистачає перспективного бачення майбутньої моделі зайнятості населення, орієнтованої не тільки і не стільки на збільшення кількісних показників і детінізацію трудових відносин, а більшою мірою спрямованої на забезпечення якісних зрушень у сфері праці, регулювання віртуального трудового простору, розвиток нових, нестандартних форм трудової діяльності.

Правила регулювання бізнесу створюють взаємозв'язок між легкістю ведення бізнесу та новими робочими місцями. Розвиток економіки неможливий без модернізації правил функціонування трудової сфери. Відхилення у бік громіздкого регулювання чи, навпаки, зайве послаблення та гіперболізована лібералізація, призводять до одного підвищення показників тіньової зайнятості та офіційного безробіття, порушення базових соціальних прав. 
Тому розвиток цифрових та інформаційних технологій повинен стимулювати розробку відповідних правил регулювання віртуальних трудових відносин як нетипових форм зайнятості. Це є важливим та актуальним завданням наукових розвідок та дослідницького пошуку.

Мета дослідження та науково-дослідницькі завдання. Зміни, що відбуваються в економічній сфері, формування інформаційного та цифрового простору як нової сфери трудової діяльності, обумовлюють мету дослідження, яке спрямоване на аналіз існуючих та вироблення нових трудоправових підходів до регламентації нетрадиційних, сучасних форм зайнятості та способів реалізації права на працю у сучасному суспільстві. Відповідно до окресленої мети будуть вирішуватися завдання визначення факторів, що впливають на розвиток типології нестандартної зайнятості, з'ясування поняття «цифровізації» та аналіз положень Концепції розвитку цифрової економіки України. Важливим напрямком дослідження також є обгрунтування необхідності суттєвого перегляду усталених в трудовому праві понять, таких як робоче місце працівника, трудова функція, режим роботи, графік роботи тощо.

Методологія дослідження. Досягнення мети і рішення поставлених у дослідженні завдань здійснюється із застосуванням методів логічного і порівняльного аналізу, систематизації та теоретичного узагальнення.

\section{2. Фактори, які впливають на розвиток віддаленої зайнятості}

Зважаючи на стрімкий розвиток цифрових та інформаційних технологій, слід відзначити, що економічний розвиток країни на даному етапі тяжіє до нових форм зайнятості та способів реалізації права на працю у сучасному суспільстві. Розвиток цифрової економіки України полягає «у створенні ринкових стимулів, мотивацій, попиту та формуванні потреб щодо використання цифрових технологій, продуктів та послуг серед українських секторів промисловості, сфер життєдіяльності, бізнесу та суспільства для їх ефективності, конкурентоздатності та національного розвитку, зростання обсягів виробництва високотехнологічної продукції та благополуччя населення» [1]. Отже, нові технології та розвиток цифрової економіки стимулюють розвиток нових форм зайнятості, на які істотно вплинув цілий ряд факторів. До яких, на нашу думку, слід віднести наступні: 
Змімення в демографії робочої сили.

Аналізуючи стан та головні проблеми ринку праці, слід насамперед звернути увагу на демографічні процеси, які відбуваються на ньому. Демографічна криза в Україні, яка характеризується щорічним скороченням чисельності населення від 350 тис. до 400 тис. осіб, вплинула безпосередньо і на чисельність активної робочої сили.

За даними Міжнародної організації праці (МОП) з 2007 р. по 2015 р. чисельність молоді у світі збільшилась на 14,2\%, при цьому зайнятість у цій групі зросла на 4,2\%, досягнувши 357 мільйонів. Рівень безробіття серед молоді виріс із 13,7\% у 2007 р. до 14,9\% у 2015 р. Цей показник значно вищий серед юнаків та дівчат, ніж серед дорослих робітників, де безробіття складає 5,1\%. Частка зайнятих молодих людей у загальній чисельності молоді в останнє десятиріччя скоротилася з 51,6\% до 47,3\% [2].

Така картина свідчить про те, що сучасному суспільству вкрай необхідні зміни, які зможуть знизити рівень безробіття серед молоді та активізувати такий значний сегмент ринку праці. При цьому слід враховувати, що молодь як суб'єкт трудових відносин, прагне і здібна до нестандартних, віддалених форм праці.

Формування працівника нового типу.

Хусаінов Р. В. та Данченко Л. Г. вважають, що «... інноваційна економіка грунтується на знаннях, і це означає, що основним капіталом будьякої економічної структури стає інтелектуальна власність, людський капітал, інноваційні розробки та «ноу-хау», а не матеріальні активи і традиційні ресурси, що ще раз свідчить про трансформацію матеріальної основи капіталу в інтелектуальну» [3, с. 25]. Погоджуючись у цілому з вказаним правовим підходом, слід зазначити, що, дійсно, для підвищення рівня зайнятості та подальшого розвитку економіки знання $€$ неодмінно важливими, але вважаємо за доцільне звернути увагу на те, що підготовка фахівця нового типу повинна здійснюватись через вплив на різні сфери його особистості: когнітивну, особистісну та професійну.

Зокрема слід говорити про такі якості, як: високу мотивацію до творчості, почуття нового, уміння мислити нестандартно, винахідливість, вміння приймати рішення у ситуаціях невизначеності, вміння відстоювати власну позицію, фахову гнучкість і мобільність, вміння вирішувати нетипові завдання, опанувати нову професію, вміння використовувати цифрові технології в роботі тощо. Крім того, кількість 
робочих місць в Україні, що потребують від працівників принаймні базового розуміння інформаційно-комунікаційних та цифрових технологій, стрімко збільшується, а вміння користуватися технологіями стає основною вимогою до персоналу, що є превалюючим чинником, який впливає на формування працівника нового типу.

Вважаємо, що внаслідок підвищення рівня інтелектуалізації праці працівник стає власником найбільш важливого і унікального засобу виробництва - свого людського капіталу. Це стимулює широке використання форм нестандартної зайнятості, оскільки саме вони дають більший рівень свободи, природно при більш високому рівні відповідальності за результати своєї праці.

Розвиток мобільних технологій.

3 огляду на масштаби розвитку та поширення нових технологій, не можна залишити осторонь той факт, що сучасна людина не може прожити повноцінний день без мобільного телефону, а поширення інформації у соціальних мережах набуло значних масштабів.

Нещодавно «стало відомо, що український бот-юрист PatentBot успішно зареєстрував першу торговельну марку в Україні. Відповідна документація, яка свідчить про успішну реєстрацію, вже передана власникам, повідомляє ресурс liga.net”. Назва цієї торгової марки та iiі призначення невідомі, але тут важливіше сам факт успішного завершення процедури. Як повідомляється, на реєстрацію торгової марки за прискореною процедурою пішло 4,5 місяці [4].

Широка мережа соціальних зв'язків.

Слід зауважити, що велика кількість людей намагається створити власний імідж та розширити своє коло зв'язків завдяки використанню соціальних мереж. Це може стосуватися, як взагалі кожної окремої особи, яка або шукає роботу, або вже ії має у тих же самих соціальних мережах, так і певної окремої категорії осіб, які шукають потенційних роботодавців - фрілансери. Як показують дослідження компанії Payoneer, Facebook став однією з найбільш зручних і популярних платформ для професійного просування і спілкування 3 клієнтами. Більше половини фрілансерів (54\%) використовують Facebook для реклами своїх послуг у порівнянні з 38\% в 2015 р Друге місце займає LinkedIn - цю платформу для професійного спілкування використовують 40\% фрілансерів. Під час опитування в 2015 році лише $14 \%$ респондентів вказали LinkedIn в якості майданчика для пошуку роботи. 
Інноваиійна освіта.

Останнім часом багато дослідників наголошують на тому, що сучасний рівень освіти не може повністю якісно забезпечити необхідними знаннями та навичками майбутніх працівників, унаслідок чого з'являються нові форми навчання та тенденції у сфері самоосвіти. Крім того, роботодавців починають цікавити «метапрофесійні та особистісні компетенції - здатність реалізовувати певну позицію, мобільність, відкрите ставлення до світу» [5], які працівники мають розвивати в собі протягом усього часу, що вони працюють.

За останні декілька років значно збільшилася кількість інструментів для розвитку компетентностей, як для працюючого населення, так і для студентів. Зокрема значної популярності набули короткострокові освітні програми за кордоном, які «насамперед надають студентам можливість отримати концептуально нові знання або ж поглибити вже набуті, а також ознайомитися із західною системою освіти, підвищити рівень володіння іноземною мовою» [6].

Крім того, стрімко розвивається онлайн освіта у вигляді масових відкритих онлайн-курсів. «Головною особливістю і водночас перевагою масових відкритих онлайн-курсів є те, що навчатися може кожен, хто бажає (жодних вікових, територіальних, фінансових чи інших обмежень немає), у будь-який час (відеозаписи лекцій, інтерактивні завдання та форуми для обговорення доступні цілодобово) та у будьякому місці...» [7].

Та основною формою розвитку свого професійного рівня, як працівника, так і роботодавця $є$ lifelonglearning, яка визначається як «постійний творчий розвиток і вдосконалення кожної людини протягом усього життя шляхом взаємодії між знаннями, що здобуті на початкових етапах освіти, і знаннями, здобутими на подальших етапах, а також взаємодія між теоретичними та практичними знаннями, що підтверджуються компетентністю в подальшому їх практичному використанні. Вона охоплює базову професійну і подальшу освіту, передбачає послідовне поєднання навчальної і професійної діяльності в освітніх закладах, професійне самовдосконалення на різних життєвих етапах» [8, с. 451].

Сімейний стан (працівник із сімейними обов'язками).

Хоча сімейний стан не має жодного зв'язку з розвитком інформаційно-комунікаційних технологій про які йшлося вище, та не можна 
залишити його осторонь, бо він також є одним з факторів, що впливають на розвиток віддаленої зайнятості. Наразі, у національному законодавстві прямо не закріплена така категорія, як «працівник із сімейними обов'язками».

Слід зазначити, що сьогодні згадка про працівників із сімейними обов'язками є у Конвенції МОП № 156 «Про рівне ставлення і рівні можливості для трудящих чоловіків і жінок: трудящі із сімейними обов'язками», яка ратифікована Законом України від 22 жовтня 1999 р. і $є$ частиною національного трудового законодавства. Положення даної конвенції набули детального розвитку у Рекомендації № 165 «Про рівне ставлення і рівні можливості для трудящих чоловіків і жінок: трудящі iз сімейними обов'язками», яка зазначає, що працівники «із сімейними обов'язками, які виконують або бажають виконувати оплачувану роботу, здійснювати своє право на це, не підлягаючи дискримінації та, по змозі, гармонійно поєднуючи сімейні й професійні обов'язки» [9].

Зокрема працівниками із сімейними обов'язками, відповідно до ст. 287 проекту ТК України, визнаються мати, батько, усиновлювач, опікун, піклувальник, прийомні батьки, а в окремих випадках, передбачених цим Кодексом, - інший член сім’ї [10]. Вважаємо, що уніфікований підхід до регулювання праці чоловіків та жінок із сімейними обов'язками може забезпечити останнім рівні можливості у зайнятості та конкурентоспроможність на ринку праці. Вірогідно, і національне законодавство має враховувати зазначені тенденції.

Отже, виникнення віддаленої зайнятості, яка значно набирає оберти на сьогоднішньому ринку праці, є закономірним процесом трансформації сфери зайнятості, як в Україні, так і по всьому світу. Було доведено, що стрімкий розвиток віддаленої зайнятості обумовлюється рядом факторів, до яких належать: зміщення в демографії робочої сили, формування працівника нового типу, розвиток мобільних технологій, широка мережа соціальних зв'язків, інноваційна освіта ті сімейний стан (працівник із сімейними обов'язками).

\section{3. Цифровізація робочого місця}

У XXI столітті важливу роль у житті кожного відіграє інформаційний простір у якому він знаходиться. Слід звернути увагу на те, що застосування комп'ютерної техніки, інформаційних технологій та мережі Internet, об'єднує людей з різних країн в єдине світове співто- 
вариство, яке не має жодних обмежень. Роль мережі Internet в такому співтоваристві зростає надзвичайно швидко, а розміщена інформація $\epsilon$ не тільки найважливішим фактором спілкування, володіння новими знаннями, освіти і виховання, але також необхідним засобом супроводження товарів і послуг, укладення угод, працевлаштування, підтвердження подій, фактів тощо.

Стрімко зростає кількість і значення даних, створених або записаних в цифровому форматі. Збільшується і потреба компаній в професіоналах, здатних управляти великими масивами цифровими даними, забезпечувати їх конфіденційність і кіберзахист. Крім того, завдяки стрімко зростаючій цифровізації, з'явилася можливість виконання своїх безпосередніх трудових обов'язків віддалено від робочого місця.

17 січня 2018 року була схвалена Концепція розвитку цифрової економіки, яка зазначає, що цифровізація це «насичення фізичного світу електронно-цифровими пристроями, засобами, системами та налагодження електронно-комунікаційного обміну між ними, що фактично уможливлює інтегральну взаємодію віртуального та фізичного, тобто створює кіберфізичний простір» [11].

В епоху цифровізації економіки новим трудовим активом стають інформаційні дані та працівники, які в змозі ефективно їх використовувати. Цей процес потребує не тільки оптимізації інфраструктури, а й реформування ринку праці. Сьогодні велику кількість процесів у діяльності більшості установ автоматизовано, а програмне забезпечення є спеціалізованим, сучасним і таким, яке постійно оновлюється. Проте все частіше стратегічні рішення потребують аналітичної підтримки. Тому набувають важливості стратегічна роль і впровадження інноваційних підходів у зайнятості населення.

Основними цілями цифрового розвитку є:

- прискорення економічного зростання та залучення інвестицій;

- трансформація секторів економіки в конкурентоспроможні та ефективні;

- технологічна та цифрова модернізація промисловості та створення високотехнологічних виробництв;

- доступність для громадян переваг та можливостей цифрового світу;

- реалізація людського ресурсу, розвиток цифрових індустрій та цифрового підприємництва. 
Цифровізація здійснюється через механізм економічного зростання шляхом підвищення ефективності, продуктивності та конкурентоздатності від використання цифрових технологій. Цей принцип передбачає досягнення цифрової трансформації галузей економіки, сфер діяльності, набуття ними нових конкурентних якостей та властивостей. Всеохоплююча цифровізація має на меті комплексне та глибоке перетворення існуючих аналогових економічних, соціальних систем та сфер у нову цінність та якість для їх ефективності, розвитку, зручності використання тощо. Цифровізація створює нові можливості для інвестиційної діяльності та нові робочі місця [11]. Тобто, процес цифровізації, який було активовано Концепцією розвитку цифрової економіки та суспільства України на 2018 - 2020, став об'єктивною причиною для трансформації інституту зайнятості населення та переходу від стандартних до нових нестандартних форм зайнятості та створення нового виду робочих місць.

Трансформації, пов'язані із переходом на цифрові технології, створюють нові підходи та стилі діяльності, котрі в свою чергу ведуть до суттєвого перегляду усталеного в суспільстві поняття «робоче місце». У «цифровому» світі робочі місця перестають бути прив'язаними до фізичних місць - вони стають «цифровими», мобільними, тобто такими, що загалом не потребують постійного перебування працівника на робочому місці. Саме віртуально-цифровий світ надає потужні можливості задля постійного перебування працівника в онлайн-режимі. Цей тренд поширюється надзвичайно швидко й позитивно сприймається переважною більшістю працівників, яким подобаються гнучкі способи роботи, котрі дозволяють приділяти більше уваги клієнтам, друзям, сім'ї. Це може не тільки сприяти збереженню кваліфікованих працівників, але й збільшити податкові надходження, внески соціального страхування, а головне - впливати на ринок зайнятості [12].

Концепція «цифрових робочих місць» поширюється надзвичайно швидко у бізнес-середовищі та позитивно сприймається переважною більшістю працівників, яким подобаються гнучкі способи роботи, можливість працювати вдома, на відпочинку, тобто з будь-якого місця [11].

Відповідно до концепції «цифрове робоче місце - віртуальний еквівалент фізичного робочого місця, котрий вимагає належної організації, користування та управління, оскільки воно має стати запорукою підвищеної ефективності працівників та створення для них більш сприятли- 
вих умов праці» [11]. 3 даного визначення розуміємо, що організація має забезпечити належне функціонування типових елементів таких як, електронна пошта, інтернет та веб-конференції. Проте, основний управлінський акцент робиться на співробітника, що дозволяє визначити цифрове робоче місце не просто збірним терміном для всіх зазначених технологій.

Видимі частини цифрового робочого місця - це технології і методи роботи, які дозволяють людям об'єднуватися, спілкуватися і взаємодіяти, не обов'язково перебуваючи лицем до лиця. Одна зі статей Deloitte показує це в такий спосіб: «Цифрове робоче місце включає в себе всі технології, які люди використовують 3 метою виконання роботи на сучасному робочому місці. Ці технології варіюються від HR-додатків і бізнес-додатків до електронної пошти, миттєвих повідомлень, а також корпоративних соціальних комунікації і віртуальних зустрічей» [13].

Цифрове робоче місце сприяє гнучкості в методах виконання безпосередніх трудових обов'язків, стимулює спільну роботу та взаємодію, підтримує мобільне та інтерактивне робоче середовище, передбачає вибір технологій для роботи. Перевагами цифрових робочих місць $\epsilon$ зменшення витрат на апаратне забезпечення, офісні приміщення, відрядження тощо - зазначено у Концепції.

Ефективне цифрове робоче місце відокремлює роботу від фізичного місця розташування протягом більшої частини часу. Подібне «звільнення» людини має ряд важливих наслідків не тільки для того, де працюють люди, а й для того, як формуються команди і як люди збираються разом, щоб вирішити локальні проблеми. Віце-президент Microsoft в Західній Європі Klaus Holsec формулював це так: «У майбутньому успішними будуть ті компанії, які зламають бар'єри між людьми, їх робочим місцем і технологіями, а також дадуть можливість співробітникам бути продуктивними і креативними, де б вони не знаходилися. < ..> Це вимагає такої корпоративної культури, яка ставить на перше місце саме людей» [13].

В Україні планується перетворення робочих місць державних службовців у цифрові робочі місця. Це передбачено Концепцією розвитку цифрової економіки та суспільства України на 2018-2020 роки. Наразі вже зроблено перші кроки на шляху до такого перетворення.

Отже, можемо з упевненістю говорити про те, що процес цифровізації тягне за собою важливі структурні зміни у сфері зайнятості 
населення. Розвиваються нові форми зайнятості, що тягне за собою трансформацію такої важливої умови прі, як робоче місце, основними принципами створення якого мають бути: забезпечення співробітників мобільним зв'язком, використання мобільних бізнес-додатків, участь у відеоконференціях, правильна інфраструктура та безпечний цифровий простір.

\section{4. Віртуальний ринок праці та фріланс}

Формування глобального інформаційного середовища є об'єктивним процесом, в основі якого лежить активний розвиток інформаційно-комп'ютерних технологій та повсюдне проникнення їх у всі сфери суспільства. Перехід від індустріальної до інформаційної економіки та прискорений розвиток інформатизації суспільства обумовлюють процеси трансформації ринку праці, зміни змісту і характеру праці.

На нашу думку, особливості змісту праці в інформаційній економіці полягають в наступному:

• по-перше, підвищується рівень інтелектуалізації праці;

- по-друге, зменшується частка важкої, монотонної праці, стереотипних операцій;

- по-третє, результат праці все більше залежить від творчості, уміння приймати нестандартні рішення, орієнтуватися у значних інформаційних потоках, можливості продукувати інновації;

- по-четверте, творчість дає значні можливості для самореалізації. Продукт творчості у речовій формі близький до матеріального продукту, проте він є унікальним та не підлягає відтворенню або налагодженню масового виробництва.

Слід зазначити, що незважаючи на актуальність цифровізації суспільного життя та інноваційність економіки, яка тягне за собою реформацію ринку праці єдиного визначення віртуального ринку в цілому, та віртуального ринку праці зокрема, в наш час, поки що немає. Так, Романов А.Н., Одинцов Б.Е. розуміють під віртуальним ринком «віртуальний простір, де економічні суб'єкти за допомогою продажу і придбання комунікаційних та інформаційних послуг здійснюють комерційні операції». Бугорський В.Н. «безліч продавців і покупців певного електронного товару (продукту або послуги)». Румянцев В.Ф., Баркалов С.А., Гурєєва І.В., Кравців В.А. розуміють під віртуальним ринком «пропоновані системою Інтернет комунікаційні та інформаційні 
послуги комерційного призначення» [14]. Відповідно до нашої точки зору, видається неправомірним обмежувати віртуальний ринок придбанням тільки комунікаційних та інформаційних послуг. По суті, на віртуальному ринку можуть продаватися і купуватися товари і послуги, що мають речову форму.

Водночас Е. В. Бутурлакіна переконана, що інформаційнокомп'ютерні технології не є сутністю віртуального ринку, а об'єктивно технологічним середовищем, яке обумовлює його існування. Дослідниця вважає, що віртуальний ринок - це система економічних відносин між географічно розподіленими суб'єктами, які функціонують завдяки комунікаційним та інформаційним можливостям глобальної мережі (інтернет), з приводу купівлі-продажу товарів та послуг, де з урахуванням ринкових сигналів цілодобово, в режимі реального часу визначається їх кінцева вартість. За економічним призначенням віртуальний ринок вченими поділяється на віртуальний ринок товарів та послуг; віртуальний ринок інформації; віртуальний ринок праці [15, с. 69, 71].

Інформаційно-комп'ютерні технології змінюють не тільки процес праці, а й форму iii організації. Інформатизація трудового процесу створює передумови для існування і розвитку віртуального ринку праці. Віртуальний ринок праці характеризується наступними ознаками: по-перше, наявністю інформаційної праці, результатом якої $\epsilon$ інформаційний товар (послуга); по-друге, наявністю віртуальної інфраструктури, до складу якої входять онлайн платформи для пошуку роботи і пропонування послуг, електронні платіжні системи, інформаційні системи тощо; по-третє, наявністю віртуальних суб'єктів, таких як: замовники послуг та працівники (електронні фрілансери) [16, с. 219].

Зародження віртуального ринку праці пов'язане з інформаційними технологіями, з їхнім стрімко зростаючим потенціалом та постійним здешевленням, які відкривають значні можливості для появи нових шляхів для пошуку та пропозиції праці, а також для іiі організації, як у межах окремих компаній, так і суспільства в цілому. Б. Балансинович визначає віртуальний (електронний) ринок праці, як кібернетичне середовище, в якому відбуваються відносини з приводу обміну інформацією про вільні вакансії та наявну робочу силу і в якому (за допомогою інформаційних та комунікаційних технологій) стикаються попит i пропозиція на працю та на робочу силу [17, с. 30]. 
Ю. Ф. Камалова трактує поняття «електронного ринку праці» як нову форму узгодження інтересів роботодавців та працівників, яка характеризується специфічним змістом та характером трудової діяльності, $є$ заснованим на сучасних інформаційних технологіях [18, c. 18-19].

В. В. Рєзникова дає визначення електронному ринку праці як своєрідному сегменту ринку праці, що характеризується специфічним механізмом взаємодії основних суб'єктів цього ринку. Дослідниця наголошує на розповсюдженні та всебільшій значимості мережевих технологій на електронному ринку праці, що продукуються інформаційним сектором, зокрема Інтернет. Під впливом інформаційних технологій в цілому, й Інтернету зокрема, істотно перетворюється сфера зайнятості й соціально-трудові, господарсько-трудові відносини [19]. Н. Азьмук визначає цифровий ринок праці вчений як специфічний сегмент глобального ринку праці, на якому дистанційно формуються попит та пропозиція на трудові цифрові послуги, при цьому взаємодія його суб'єктів здійснюється виключно 3 використанням інформаційно-комп'ютерних технологій [20, с. 39].

Вищесказане дозволяє сформулювати власне визначення цифрового ринку праці - це специфічний сегмент глобального ринку праці зі специфічним предметом та сферою діяльності на якому віддалено формуються попит і пропозиція на різноманітні трудові послуги, при цьому взаємодія його суб'єктів відбувається виключно за допомогою сучасних інформаційно-комп'ютерних технологій.

Головна стратегія віртуальної інфраструктури віртуального ринку праці пов'язана з орієнтацією на забезпечення активної підтримки інноваційних процесів, які відбуваються в різних галузях національної економіки 3 метою практичної реалізації інноваційних інформаційних продуктів та задоволення всезростаючих потреб суспільства. Глобальна стратегічна мета функціонування віртуальної інфраструктури віртуального ринку праці - забезпечення конкурентоспроможності національного ринку праці у довгостроковому періоді, сприяння розвитку інноваційного та інтелектуального потенціалу суспільства.

Важливою складовою віртуального ринку праці вважається його, своєрідна за своєю природою, віртуальна інфраструктура, яка динамічно замінює традиційну інфраструктуру та використовує он-лайнові технології. До складу віртуальної інфраструктури ринку праці вчені 
[16, с. 220] включають: онлайн платформи для пошуку роботи і пропонування послуг; електронні платіжні системи; інформаційні системи тощо.

О. Сєнокосова виділяє в мережевій інфраструктурі віртуального ринку праці окремі інститути в вигляді бірж праці для IT-фахівців, соціальних мереж і груп, для різних професій, для міст, в вигляді віртуальної інфраструктури віртуального ринку праці. О. Сєнокосова включає мережеві формальні та неформальні інститути ринку праці. Мережеві формальні інститути ринку праці - це електронний уряд, електронна податкова інспекція, електронна поліція, безпечна інформаційна інфраструктура, правове регулювання діяльності в мережі Інтернет [21, с. 144].

Вважаємо, що «віртуальна інфраструктура» віртуального ринку праці - це мережева система інститутів ринку праці; яка завдяки використанню інформаційно-комп'ютерних технологій та мережі інтернет, формує нові, гнучкі умови для дистанційної, цифрової зайнятості та цілодобової праці, забезпечуючи однаковий доступ до інформації та даючи можливість знижувати затрати на пошук, як потенційного працівника, так і відповідного місця роботи, розвиває i «нового працівника», і «нового роботодавця», які набувають нових компетенцій у сфері праці.

Отже, сьогодні віртуальний ринок праці показує стабільний приріст з моменту появи перших хед-хантінгових ресурсів. Зараз це вже не лише сайти 3 пошуку роботи, а й фріланс-біржі, краудфандингові платформи, професійні соціальні мережі, групи і сторінки в соціальних мережах, кар'єрні сайти чи розділи компаній і організацій. Сайти рекрутингових компаній і кар'єрних консультантів, служб зайнятості та профільних асоціацій також $є$ активними учасниками трудового віртуального простору - нарівні з профільними онлайн-сервісами та мобільними додатками [22].

До найпопулярніших інтернет-бірж праці світового рівня можна віднести "Elance", "Freelance Switch Jobs", “oDesk". За даними офіційного сайту www.elance.com, однієї 3 найбільших онлайнових фріланс-бірж, станом на 2016 рік на ній були зареєстровані понад 10 мільйонів фрілансерів [23]. Розвивається також ринок українських фріланс-бірж, де фрілансери можуть реєструватися та працювати безкоштовно, а за бажання оформити «угоду без ризику», яка дає змогу 
отримати гарантію оплати, а також гарантію повернення коштів у разі невиконання угоди фрілансером.

Серед найпопулярніших інтернет-бірж в Україні слід назвати такі: https://freelancehunt.com, https://freelance.ua, https://www.weblancer.net, https://free-lance.ua, https://kabanchik.ua/freelance, https:/globalfreelance. ua. Відповідні інтернет-платформи забезпечують офіційні договори, які дають змогу вести діяльність з фрілансу офіційно.

На вказаних онлайнових платформах формується пропозиція робочої сили і попит на неї фіксується, тут також формуються умови найму, оплати і оцінка результатів праці. Цифрова зайнятість реалізується в двох основних формах: електронний фріланс і електронний аутсорсинг.

Електронний фріланс є перспективною гнучкою формою зайнятості, яка дає можливість дистанціювати працівника від роботодавця. Концепцію віддаленої роботи (remotework) обгрунтував Дж. Ніллес ще на початку 1970-х років, коли він керував першим подібним проектом в університеті Південної Каліфорнії, проте іiї повноцінна масова реалізація стала можлива пізніше завдяки подальшому розвитку технологій зв'язку, здатних оперативно передавати великі обсяги інформації [24].

Сам же термін e-lancer - «електронний фрілансер»вперше з'явився в 1998 р в статті Томаса Малоун іРоберта Лойбахера і був утворений за аналогією з неологізмамі e-mail - електронна пошта, e-business електронний бізнес. Можна також зустріти похожий термін web-lancer «мережевий фрілансер» [25].

Електронний фрілансер - це фрілансер, який здійснює свою трудовою діяльність віддалено з використанням інформаційно-комунікаційних технологій. Необхідний сучасний набір електронного фрілансера, для спілкування з клієнтами і отримання завдань, складається 3 наявності: Інтернету, комп'ютера, електронної пошти, ICQ, Skype, мобільного телефону, пластикової карти або електронного гаманця Webmoney.

Згідно даних спільного звіту двох найбільших онлайн-платформ "Elance" i “Odesk” на кінець 2014 року кількість зареєстрованих на них фрілансерів становило - 9,7 млн осіб, а роботодавців - 3,8 млн. Тільки на цих двох платформах сукупний заробіток фрілансерів за період 3 2009 по 2014 р зріс з трохи менше 500 млн дол США до 3,2 млрд дол. США. При цьому середній заробіток за час роботи варіюється від 
13 до 27 дол. США в залежності від складності виконання робіт і статусу розробника [26].

За оцінками експертів біржі Elance, до 2020 р фрілансери складуть $60 \%$ всього світового ринку праці, а оборот ринку віддаленої роботи досягне 46 млрд. дол. США [27].

Електронний фріланс охоплює досить широкий спектр видів економічної діяльності: програмування, створення контенту і переклад, маркетингові дослідження, продаж, консалтинг, фінансовий облік, адміністрування. Згідно з даними спільного звіту "Elance" i “Odesk" найбільшу питому вагу в структурі послуг мають: розробка технологій (50\%), адміністративна підтримка (12\%), створення контенту і переклад (12\%), дизайн і мультимедійні розробки (9\%), розробка мобільних додатків (8\%). Замовниками послуг у фрілансерів є такі компанії, як: "Microsoft", "Disney", “Amazon", "Cisco", "OpenTable", "Pinterest" і багато інших [27].

Загальновідомим фактом $є$ те, що українські програмісти та фахівці в галузі інформаційного забезпечення є одними з найкращих. У той же час, за статистикою, переважна більшість 3 них працює на іноземні компанії, часто не оформлюючи належним чином такі трудові відносини.

Так було проведено дослідження ринку аутсорс-програмування Східної Європи, компанію є “Тор \$ dev" - сервіс пошуку програмістів та IT-рекрутингу. У цьому дослідженні проаналізовані дані більше 88 тис. профілів фрілансерів і 260 тис. проектів на загальну суму більш ніж 350 млн дол. США, надані найбільшими фріланс-біржами. За його результатами Україна в 2014 р. є лідером серед країн Східної Свропи у сумі замовлень на ІТ-послуги. Частка України на цьому ринку складає $33 \%$, другу і третю позицію займають Росія (21,8\%) і Румунія (9\%) [28].

Найбільшими центрами IT-фріланса в 2014 р. в Східній Європі за обсягами виконаних замовлень, стали такі українські міста: Харків (6,74\%), Київ(6,63\%), Львів (3,33\%) та Запоріжжі $(3,07 \%)$. п'яту і шосту позицію в рейтингу займають російські міста: Омськ $(3,06 \%)$ і Москва (2,88\%) [29]. представлені дані свідчать про те, що Україна $€$ одним з найбільших експортерів талантів в сфері інформаційних послуг для розвинених країн.

Фріланс, як явище, отримав надзвичайно широку поширеність 3 розвитком Інтернету. Варто зазначити, що на міжнародному рівні вже 
досить давно діють такі нормативні акти, як Конвенція Міжнародної організації праці «Про надомну працю» № 177 від 20.06.1996 та Конвенція Міжнародної організації праці про гідну працю домашніх працівників (фрілансерів) № 189 від 16.06.2011, які покликані врегульовувати такого роду правовідносини. Вітчизняне ж законодавство до таких нововведень не поспішає, адже жодна 3 цих конвенції не була ратифікована Україною, хоча завдяки правильному нормативно-правовому регулюванню інформаційної сфери з'являється потенційна можливість залучення багатомільйонних інвестицій в економіку України.

Головною проблемою $є$ те, що багато фрілансерів ніколи не укладають трудового договору. Крім того, в даний час чимало незалежних фахівців, які оформили свою діяльність як індивідуальні підприємці. Це дає їм можливість будувати відносини з замовниками на основі цивільно-правових договорів. При цьому робота таких індивідуальних підприємців має ознаки фрілансу, тобто вони працюють віддалено, поза місцем розташування замовника із застосуванням сучасних інформаційних технологій. В основному індивідуальні підприємці виконують роботу особисто, але деякі з них додатково можуть наймати співробітників для виконання окремих функцій, які в разі задоволення критеріям з нашого визначення, також будуть фрілансерами.

\section{5. Висновки}

Підводячи підсумок даного наукового дослідження зазначимо, що сьогодні державі не вистачає перспективного бачення майбутньої моделі зайнятості населення, орієнтованої не тільки на збільшення кількісних показників і детінізацію трудових відносин, а й перш за все на забезпечення якісних зрушень у сфері праці.

Наразі віддалена зайнятість поширюється дуже швидко, усе більше людей надають перевагу віддаленій самостійній роботі на замовлення 3 огляду на низку критеріїв: зміщення в демографії робочої сили, формування працівника нового типу, розвиток мобільних технологій, широка мережа соціальних зв'язків, інноваційна освіта ті сімейний стан (працівник із сімейними обов'язками).

Процес цифровізації тягне за собою модернізацію робочого місця, основними принципами створення якого мають бути: забезпечення співробітників мобільним зв'язком, використання мобільних біз- 
нес-додатків, участь у відеоконференціях, правильна інфраструктура та безпечний цифровий простір.

В умовах інформаційного суспільства цифровий ринок праці виступає новим сегментом у складі наявного ринку, частка і вагомість якого постійно зростає. Однак, на жаль доводиться констатувати, що, не зважаючи на велику кількість осіб, які зайняті на цифровому ринку праці, у діючому трудовому законодавстві відсутня нормативно-правова регламентація такої форми зайнятості як віддалена праця, що не дозволяє особам, які займаються фрілансом, у повному обсязі реалізувати право на працю, яке гарантовано Конституцією України.

У рамках правового регулювання повинна відбутися легалізація цифрових трудових відносин, повинен бути вирівняний статус усіх учасників соціально-трудових відносин: і тих, які працюють на умовах постійної/тимчасової зайнятості, і тих, які задіяні на засадах віддалених форм зайнятості (фріланс, аутсорсинг тощо). За допомогою правових засобів повинні бути забезпечені гідні умови роботи для суб'єктів цифрового ринку праці на рівні з іншими працівниками, задіяними в операційній діяльності підприємств.

Виходячи з вищенаведеного пропонуємо врегламентувати у проекті Трудового кодексу України віддалену форму зайнятості та закріпити визначення поняття цифровий ринок праці як «специфічний сегмент глобального ринку праці зі специфічним предметом та сферою діяльності, на якому віддалено формуються попит і пропозиція на різноманітні трудові послуги, при цьому взаємодія його суб'єктів відбувається виключно за допомогою сучасних інформаційно-комп'ютерних технологій».

\section{Список літератури:}

1. Концепція розвитку цифрової економіки та суспільства України на 2018-2020 роки Схвалено розпорядженням Кабінету Міністрів України від 17 січня 2018 p. № 67-p [Електронний ресурс]. - Режим доступу: https://www. kmu.gov.ua/ua/npas/pro-shvalennya-koncepciyi-rozvitku-cifrovoyi-ekonomiki-tasuspilstva-ukrayini-na-20182020-roki-ta-zatverdzhennya-planu-zahodiv-shodoyiyi-realizaciyi

2. Report "Global Employment Trends for Youth 2016" [Електронний pecypc]. - Режим доступу: http://www.ilo.org/trends.

3. Хусаінов Р. В., Данченко Л. Г. Інституційні умови та механізми активізації інноваційної діяльності в Україні / Р. В. Хусаінов, Л. Г. Данченко // Стан та проблеми розвитку національної економіки в умовах перманентних кри- 
зових явищ / за ред. д.е.н., професора О. О. Непочатенко. - Умань: Видавець «Сочінський», 2015. - 236 с.

4. Боты-юристы в Украине: первая зарегистрированная торговая марка и развод онлайн [Електронний ресурс]. - Режим доступу: https://itc.ua/news/ botyi-yuristyi-v-ukraine-pervaya-zaregistrirovannaya-torgovaya-marka-i-razvodonlayn/

5. Нові тренди бізнес-освіти [Електронний ресурс]. - Режим доступу: http://kibit.edu.ua/news/novye-trendy-biznes-obrazovaniya/

6. Короткострокові академічні програми [Електронний ресурс]. - Режим доступу: http://yourinsa.com/ua/programi/korotki-akademichni-programi.

7. Тепла М. Масові відкриті онлайн-курси в Україні: сучасні тенденції розвитку, можливості та досягнення [Електронний ресурс] / Мирослава Тепла. 2016. - Режим доступу: http://ir.kneu.edu.ua/bitstream/2010/20402/1/82-84.pdf.

8. Задорожна Н. Т. Енциклопедія освіти / Н. Т. Задорожна, Т. В. Кузнецова. Медіа-освіта. - Акад. пед. наук України / Гол.ред. В. Г. Кремень К.: Юрінком Інтер, 2008. - 1040 с.

9. Рекомендація щодо рівних можливостей та рівного ставлення до працівників чоловіків і жінок: працівники із сімейними обов'язками [Електронний pecypc] - Режим доступу: http://zakon2.rada.gov.ua/laws/show/993_275.

10. Проект Трудового кодексу України [Електронний ресурс] - Режим доступу: http://w1.c1.rada.gov.ua/pls/zweb2/webproc4_1?pf3511=53221.

11. Розпорядження КМУ від 17 січня 2018 р. № 67-p «Про схвалення Концепції розвитку цифрової економіки та суспільства України на 2018 2020 роки та затвердження плану заходів щодо іiі реалізації». [Електронний peсурс] - Режим доступу: https://www.kmu.gov.ua/ua/npas/pro-shvalennyakoncepciyi-rozvitku-cifrovoyi-ekonomiki-ta-suspilstva-ukrayini-na-20182020roki-ta-zatverdzhennya-planu-zahodiv-shodo-yiyi-realizaciyi.

12. Проект Цифрова адженда України - 2020 («Цифровий порядок денний» - 2020) Концептуальні засади (версія 1.0) [Електронний ресурс]. 2016. - Режим доступу: https://ucci.org.ua/uploads/files/58e78ee3c3922.pdf.

13. What a Digital Workplace Isand What It Isn't [Електронний ресурс] - Режим доступу: https://www.cmswire.com/cms/social-business/what-a-digital-workplaceis-and-what-it-isnt-027421.php.

14. Проблемы экономики и менеджмента: информ.-аналит. журн. [текст] / учредитель ИП Самохвалов А.В. - 2011. - октябрь.

15. Бутурлакіна Е. В. Виртуальный рынок как новый тип рынка в информационной экономике / Е. В. Бутурлакіна // Современная экономика: проблемы и решения. - 2012. - № 5 (29). - С. 65-75.

16. Азьмук Н. А. Трансформація процесу праці в інформаційній економіці / Н. А. Азьмук // Соціально-трудові відносини: теорія та практика. - 2014. № 2 (8). - С. 217-223.

17. Баласинович Б. Вплив інформаційно-комунікаційних технологій на ринок праці і зайнятість населення / Б. Баласинович // Україна: аспекти праці. - 2005. - № 1. - С. 30-34.

18. Камалова Ю. Ф. Особенности трудового посредничества на основе современных информационных технологий : автореф. дис. на соискание 
учен. Степени канд. экон. наук : 08.00.05 «Экономика и управление народным хозяйством (экономика труда)» / Ю. Ф. Камалова. - М., 2004. - 26 с.

19. Рєзнікова В. В. Правове регулювання посередництва на ринку праці / В. В. Рєзнікова // Університетські наукові записки, 2010. - № 4 (36). - С. 104-115.

20. Азьмук Н. А. Сутність, особливості та функції цифрового ринку праці / Н. А. Азьмук // Економіка, 2015. - № 5 (170). - С. 38-43.

21. Сенокосова О. В. Сетевые институты рынка труда / О. В. Сенокосова // Изв. Сарат. ун-та. Сер. Экономика. Управление. Право. - 2014. - Т. 14, вып. 1, ч. 2. - С. 142-146.

22. Пошуки вакансії в Мережі: особливості віртуального ринку праці [Електронний ресурс] - Режим доступу: http://forbes.net.ua/ua/opinions/1424726poshuki-vakansiyi-v-merezhi-osoblivosti-virtualnogo-rinku-praci.

23. Офіційний сайт інтернет-біржі “Еlance” [Електронний ресурс]. Режим доступу: http://www.elance.com

24. Nilles J. Managing Telework: Strategies for Managing the Virtual Workforce/J. Nilles.-N.-Y.: Wiley, 1998 [Електронний ресурс].-Режим доступу: http://trove.nla.gov.au/work/7769072?q\&versionId=8952146.

25. T. W. Malone, R. J. Laubacher. The dawnofthe e-lance economy. Harvard Business Review. September-October 1998, Reprint 98508.

26. Online Work Report. United States, 2014 Full Year Data. - [Electronic resource] // Elance-odesk: [website]. - [online] Availableat: http://elance-odesk. com/online-work-report-us

27. Global Freelancer Survey. - [Electronicresource] // Elance: [website] [online] Availableat: https://www.elance.com.

28. Дослідження сервісом top $\$$ dev ринку аутсорс-програмування Східної Європи [Електронний ресурс]. - Режим доступу http://topsdev.org/blog/obzorrinka-freelance-2014.htm.

29. Дослідження: університети та міста на ринку аутсорс-програмування Східної Європи [Електронний ресурс]. - Режим доступу http://topsdev.org/ blog/obzor-universitiesfreelance-2014.htm.

\section{References:}

1. (2018) Koncepcija rozvytku cyfrovoji ekonomiky ta suspiljstva Ukrajiny na 2018-2020 roky Skhvaleno rozporjadzhennjam Kabinetu Ministriv Ukrajiny vid 17 sichnja 2018 r. \# 67-r [Concept of development of digital economy and society of Ukraine for 2018-2020 Approved by the order of the Cabinet of Ministers of Ukraine dated January 17, 2018 No. 67-p]. Available at: https://www.kmu.gov.ua/ ua/npas/pro-shvalennya-koncepciyi-rozvitku-cifrovoyi-ekonomiki-ta-suspilstvaukrayini-na-20182020-roki-ta-zatverdzhennya-planu-zahodiv-shodo-yiyi-realizaciyi (accessed 01 March 2018).

2. Report "Global Employment Trends for Youth 2016" Available at: http://www.ilo.org/trends. (accessed 03 March 2018).

3. Khusainov R. V., Danchenko L. Gh.(2015) Instytucijni umovy ta mekhanizmy aktyvizaciji innovacijnoji dijaljnosti v Ukrajini [Institutional Conditions and Mechanisms for Activating Innovation in Ukraine]/ Stan ta problemy rozvytku nacionaljnoji ekonomiky $v$ umovakh permanentnykh kryzovykh javyshh [Status and 


\section{Hnidenko Viktoriia, Kaplina Halyna}

Problems of the Development of the National Economy in Conditions of Permanent Crisis] Umanj, Sochinsjkyj, pp. 25-28.

4. Boty-jurysty v Ukrayne: pervaja zareghystryrovannaja torghovaja marka y razvod onlajn [Lawyers in Ukraine: the first registered trademark and online distribution]. Available at: https://itc.ua/news/botyi-yuristyi-v-ukraine-pervayazaregistrirovannaya-torgovaya-marka-i-razvod-onlayn/(accessed 27 February 2018).

5. Novi trendy biznes-osvity [New trends in business education]. Available at: http://kibit.edu.ua/news/novye-trendy-biznes-obrazovaniya/(accessed 25 February 2018).

6. Korotkostrokovi akademichni proghramy [Short-term academic programs]. Available at: http://yourinsa.com/ua/programi/korotki-akademichni-programi. (accessed 27 February 2018).

7. Tepla M. (2016) Masovi vidkryti onlajn-kursyv Ukrajini: suchasni tendenciji rozvytku, mozhlyvosti ta dosjaghnennja [Massive open online courses in Ukraine: current trends, opportunities and achievements] Available at: http://ir.kneu.edu.ua/ bitstream/2010/20402/1/82-84.pdf. (accessed 27 February 2018).

8. Zadorozhna N. T. (2008) Encyklopedija osvity [Encyclopedia of Education]. Kiev: Jurinkom Inter. (in Ukrainian)

9. Rekomendacija shhodo rivnykh mozhlyvostej ta rivnogho stavlennja do pracivnykiv cholovikiv $i$ zhinok: pracivnyky iz simejnymy obov'jazkamy [Recommendation on Equal Opportunities and Equal Treatment for Men and Women Workers: Workers with Family Responsibilities] Available at: http://zakon2.rada.gov.ua/laws/show/993 275. (accessed 28 February 2018).

10. Proekt Trudovogho kodeksu Ukrajiny [Draft Labor Code of Ukraine]. Available at: http://w1.c1.rada.gov.ua/pls/zweb2/webproc4_1?pf3511=53221. (accessed 03 March 2018).

11. Rozporjadzhennja KMU vid 17 sichnja 2018 r. \# 67-r "Pro skhvalennja Koncepciji rozvytku cyfrovoji ekonomiky ta suspiljstva Ukrajiny na 2018-2020 roky ta zatverdzhennja planu zakhodiv shhodo jiji realizaciji”. [Decree of the Cabinet of Ministers of Ukraine dated January 17, 2018, No. 67-p "On Approval of the Concept for the Development of the Digital Economy and Society of Ukraine for 2018-2020 and approval of the plan of measures for its implementation".]. Available at: https://www.kmu.gov.ua/ua/npas/pro-shvalennya-koncepciyi-rozvitku-cifrovoyiekonomiki-ta-suspilstva-ukrayini-na-20182020-roki-ta-zatverdzhennya-planuzahodiv-shodo-yiyi-realizaciyi. (accessed 01 March 2018).

12. (2016) Proekt Cyfrova adzhenda Ukrajiny - 2020 ("Cyfrovyj porjadok dennyj" - 2020) Konceptualjni zasady (versija 1.0) [Digital Aidge Project of Ukraine 2020 (Digital Agenda - 2020) Conceptual framework (version 1.0)]. Available at: https:/ucci.org.ua/uploads/files/58e78ee3c3922.pdf. (accessed 01 March 2018).

13. What a Digital Workplace Isand What It Isn't. Available at: https://www.cmswire.com/cms/social-business/what-a-digital-workplace-is-andwhat-it-isnt-027421.php. (accessed 04 March 2018).

14. Samokhvalov A.V. (2011) Problemy ekonomyky y menedzhmenta: ynform.analyt. zhurn. [Problems of Economics and Management: inform. Analyst. (in Russian) 


\section{Analysis of trends for development of distantly employment in Ukraine}

15. Buturlakina E. V. (2012) Virtualnyiy ryinok kak novyiy tip ryinka V informatsionnoy ekonomike [Virtual market as a new type of market in the information economy]. Modern Economics: Problems and Solutions, vol. 5, no. 29, pp. $65-75$.

16. Azjmuk N. A. (2014) Transformacija procesu praci v informacijnij ekonomici [Transformation of the labor process in the information economy]. Social-Labor Relations: Theory and Practice, vol. 2, no. 8, pp. 217-223.

17. Balasynovych B. (2005) Vplyv informacijno-komunikacijnykh tekhnologhij na rynok praci i zajnjatistj naselennja [Influence of information and communication technologies on the labor market and employment of the population]. Ukraine: aspects of labor, no 1, pp. $30-34$.

18. Kamalova Ju. F. (2004) Osobennosti trudovogo posrednichestva na osnove sovremennyih informatsionnyih tehnologiy [Features of labor mediation on the basis of modern information technologies]. (PhD Thesis)/

19. Rjeznikova V. V. (2010) Pravove reghuljuvannja poserednyctva na rynku praci [Legal regulation of mediation in the labor market] University scientific notes vol.4 no.3, pp. 104-115.

20. Azjmuk N. A. (2015) Sutnistj, osoblyvosti ta funkciji cyfrovogho rynku praci [Essence, features and functions of the digital labor market]. Economy, vol. 5 no. 170 , pp. $38-43$.

21. Senokosova O. V. (2014) Setevyie institutyi ryinka truda [Network labor market institutes]. Economics Management Right, vol.14, no. 2, pp. 142-146.

22. Poshuky vakansiji v Merezhi: osoblyvosti virtualjnogho rynku praci Available at: http://forbes.net.ua/ua/opinions/1424726-poshuki-vakansiyi-vmerezhi-osoblivosti-virtualnogo-rinku-praci. (accessed 04 March 2018).

23. Oficijnyj sajt internet-birzhi "Elance" Available at: http:/www.elance.com (accessed 05 March 2018).

24. Nilles J. (1998) Managing Telework: Strategies for Managing the Virtual Workforce Available at: http://trove.nla.gov.au/work/7769072?q\&versio $\mathrm{nId}=8952146$. (accessed 04 March 2018).

25. T. W. Malone, R. J. Laubacher. (1998) The dawnofthe e-lance economy. Harvard Business Review. September-October 1998, Reprint 98508.

26. Online Work Report. United States, 2014 Full Year Data. Available at: http://elance-odesk.com/online-work-report-us (accessed 04 March 2018).

27. Global Freelancer Survey. Available at: https://www.elance.com. (accessed 05 March 2018).

28. Doslidzhennja servisom top \$ dev rynku autsors-proghramuvannja Skhidnoji Jevropy [Research by the service of top $\$$ dev of outsourcing programming in Eastern Europe]. Available at: http://topsdev.org/blog/obzor-rinka-freelance-2014. htm. (accessed 06 March 2018).

29. Doslidzhennja: universytety ta mista na rynku autsors-proghramuvannja Skhidnoji Jevropy [Research: Universities and cities in the outsourcing programming market of Eastern Europe]. Available at: http://topsdev.org/blog/ obzor-universitiesfreelance-2014.htm. (accessed 06 March 2018). 